\title{
Rojas Rojas, Rolando. La revolución de los arrendires: una historia personal de la reforma agraria
}

Lima: Instituto de Estudios Peruanos, 2019, 193 pp.

Recibido:09/08/2020 - Aceptado: 21/10/2020 - Publicado: 12/03/2021

La provincia de La Convención, Cusco, suele ocupar un espacio prominente en los relatos históricos sobre la Reforma Agraria peruana, por ser el lugar donde se aplicó, en 1962, la primera ley para tal fin, durante un periodo de intensa agitación campesina asociada en el imaginario popular con la figura de Hugo Blanco. Menos conocidos son los sucesos que antecedieron a este momento de confrontación y que de alguna manera vislumbraron la etapa de cambios que se venía. El 28 de agosto de 1956, el poderoso hacendado Alberto Duque, dueño de la hacienda San Pedro y de otras propiedades, fue asesinado por el joven Nazario Gamarra, como resultado de lo que posteriormente se denominaría "la conspiración de los arrendires". Dos de los campesinos arrendatarios de la hacienda, Eduardo Celis y Víctor Valencia, habían planificado el acto junto con el comerciante-arrendatario Tomás Rojas Pillco, y los tres, junto con Gamarra, pasarían 16 años en prisión, hasta ser liberados por el régimen militar en 1972.

En su libro La revolución de los arrendires: una historia personal de la Reforma Agraria, el nieto de Rojas Pillco, el historiador Rolando Rojas Rojas, reconstruye el suceso en un relato que combina el recuerdo familiar con las fuentes históricas, y el análisis de las relaciones de clase en el valle de La Convención con la reconstrucción de las personalidades de los actores. Para el autor, el contexto de la muerte de Duque fue el creciente enfrentamiento entre los hacendados, "incisivos empresarios" quienes por varias décadas habían promovido la colonización de esta región de selva alta por parte de campesinos de la sierra mediante contratos que otorgaban el derecho a cultivar una parcela a cambio de trabajo gratuito y otras obligaciones. La muerte de Duque tuvo lugar

Citar como: Rojas Rojas, Rolando. La revolución de los arrendires: Una historia personal de la reforma agraria. Revista de antropología núm. 8: 133 - 135. http://dx.doi.org/10.15381/antropologia.v0i8.19812 
también en el contexto de la formación de una clase de campesinos arrendires que empezaban a prosperar gracias a los altos precios del café y que buscaban liberarse de las ataduras y opresiones correspondientes a una etapa anterior del desarrollo capitalista del valle.

Los hacendados se aprovechaban de la emergencia de prácticas "semilegales" entre los arrendatarios, como la compra y venta de los derechos de uso de las parcelas y la contratación de jornaleros para cumplir las obligaciones laborales en la hacienda, como argumento para denunciarlos por incumplimiento de contrato y desalojarlos con la ayuda de la policía, de esa manera apropiándose del duro trabajo que el campesino había invertido en el desbrozo y puesta en producción del terreno. Fueron estas ofensivas de desalojo las que llevaron al conflicto específico del hacendado Duque con los arrendires Celis y Valencia, y con Rojas Pillco, un sastre urubambino convertido en comerciante en Quillabamba y que también había adquirido algunos arriendos. Tras el asesinato, los conspiradores son rápidamente apresados; pero al año siguiente surge, por primera vez en el valle, un dinámico movimiento sindical campesino, asesorado por abogados comunistas del Cusco, que culminó en la fundación, a fines de 1958, de la Federación Provincial de Campesinos de La Convención y Lares. Si bien este movimiento es duramente reprimido, atrae la atención del militante trotskista cusqueño Hugo Blanco, quien se instala como subarrendatario en una hacienda del valle y logra, desde adentro, impulsar la revitalización y radicalización de los sindicatos, culminando en 1962 en las tomas de las haciendas por parte de los campesinos de La Convención (proceso ratificado luego por el gobierno de Pérez Godoy) y acelerando la dinámica histórica que eventualmente conduciría a la Reforma Agraria general de 1969.

Además de narrar esta historia regional desde una mirada personal y familiar, el trabajo de Rojas nos invita a pensar en la relación entre estructura y evento: ¿la conspiración de Celis, Valencia y Rojas Pillco, planificada en la tienda de este último, fue el detonante de los posteriores sucesos de La Convención, con grandes implicancias para la historia social y política del país, o estaba esta ya determinada por un proceso inexorable que conduciría a la Reforma Agraria? Si bien resulta difícil no pensar en una conexión, un mérito del autor es que no intenta forzarla más allá de lo que las fuentes permiten, aunque cita los recuerdos de dirigentes campesinos según los cuales la noticia del asesinato del hacendado "corrió como reguero de pólvora" (p. 89).

Otro aspecto de particular interés, desde la óptica de la antropología histórica, es la forma cómo el autor, lejos de confiarse únicamente del recuerdo familiar, lo contrasta, a la manera de Rashomon, con las narrativas de los descendientes de Celis y Valencia, cada una de las cuales cuenta una historia diferente sobre la manera en que se dio la confesión del acto ante la policía. Es digna de resaltar también la forma cómo el autor entrelaza las distintas memorias 
de sus entrevistados, así como las evidencias documentales de periódicos de la época y otras fuentes escritas, con el recuerdo personal: A fines de los años setenta, huyendo de la represión del gobierno de Morales Bermúdez contra los organizadores del Paro General de 1977 (entre los cuales se encontraba su padre), el niño Rolando Rojas y su familia se refugian en Quillabamba, donde conoce a su abuelo materno, Tomás Rojas Pillco, ya liberado de la prisión pero rezagado económicamente - por los años perdidos en la cárcel— en medio de la creciente prosperidad de aquella sociedad de pequeños propietarios y comerciantes que él había ayudado a crear.

Un aspecto que deja insatisfecho al lector es el hecho que el autor recurra a Michel Foucault para desarrollar un tema tal como la justicia popular — de tanta riqueza y profundidad en el Perú- habiendo una literatura amplia sobre el tema desde la historia y la antropología. De todas maneras, el libro de Rojas constituye un importante aporte a la comprensión histórica de las luchas sociales en el Perú del siglo XX, así como un modelo de articulación entre lo personal y lo colectivo, y entre la memoria y la historia.

\section{Federico Helfgott}

https://orcid.org/0000-0003-1203-354X

Universidad Nacional Mayor de San Marcos

fhelfgotts@unmsm.edu.pe 
